\title{
Nucleotide sequence and taxonomic value of the major outer membrane protein gene of Chlamydia pneumoniae IOL-207
}

\author{
M. W. Carter, ${ }^{1 *}$ S. A. H. Al-Mahdawi, ${ }^{2}$ I. G. Giles, ${ }^{3}$ J. D. Treharne, ${ }^{4}$ M. E. Ward ${ }^{1}$ and \\ I. N. Clarke ${ }^{1}$ \\ ${ }^{1}$ Department of Microbiology, University of Southampton, Faculty of Medicine, Southampton General Hospital, Tremona \\ Road, Southampton SO9 $4 X Y, U K$ \\ ${ }^{2}$ Institute of Child Health, Department of Paediatric Cardiology, 30 Guilford Street, London WC1N 1EH, UK \\ ${ }^{3}$ Department of Biochemistry, University of Southampton, School of Biological Sciences, Bassett Crescent East, \\ Southampton SO1 3TU, UK \\ ${ }^{4}$ Institute of Ophthalmology, Section of Virology, Judd Street, London WC1H 9QS, UK
}

(Received 16 July 1990; revised 10 October 1990; accepted 25 October 1990)

\begin{abstract}
Chlamydia pneumoniae IOL-207 genomic DNA was hybridized with a $1.5 \mathrm{~kb}$ labelled DNA probe containing the $3^{\prime}$ region of the coding sequence for the major outer membrane protein (MOMP) of $C$. trachomatis serovar L1. An $8.5 \mathrm{~kb} B g l \mathrm{II}$ fragment containing the complete MOMP gene was cloned into $\lambda E M B L 3$. Two hybridizing EcoRI fragments were sub-cloned into the $\lambda$ ZAP II cloning vector and the resulting plasmids were used as templates for sequencing both strands of the $C$. pneumoniae MOMP gene. Computer taxonomic studies using the nucleotide and inferred amino acid sequence of the MOMP of $C$. pneumoniae IOL-207 and all known chlamydial MOMP sequences supported the designation of $C$. pneumoniae as a new species, but electron microscope studies suggested that the presence of pear-shaped elementary bodies (EBs) may not be a reliable taxonomic criterion.
\end{abstract}

\section{Introduction}

The Chlamydiae are obligate intracellular bacteria characterized by a unique growth cycle and responsible for a wide variety of diseases in man and animals. Three species of the genus Chlamydia are recognized: $C$. trachomatis, $C$. psittaci and the newly designated species C. pneumoniae (Grayston et al., 1989a).

C. pneumoniae is an increasingly identified cause of pneumonia and acute respiratory disease in man (Grayston et al., 1989 b; Marrie et al., 1987). A high proportion of adults from different countries had antibodies to $C$. pneumoniae (Forsey et al., 1986; Grayston et al., 1989b), implying a high prevalence of these infections. Justification for designating the TWAR agent as a new species of Chlamydia was based on the differing ultrastructural

Abbreviations: BGMK, Buffalo Green Monkey Kidney; CDC, Center for Disease Control, Atlanta, GA, USA; EB, elementary body; $\mathrm{mAb}$, monoclonal antibody; micro-IF, micro-immunofluorescence; MOMP, major outer membrane protein; ORF, open reading frame; PCR, polymerase chain reaction.

The nucleotide sequence data reported in this paper have been submitted to GenBank, and have been assigned the accession number M34942. morphology of the infectious elementary bodies (EBs) (Chi et al., 1987; Kuo et al., 1988), the lack of DNA homology $(<10 \%)$ with either $C$. trachomatis, or $C$. psittaci (Cox et al., 1988), the unique DNA restriction endonuclease patterns (Campbell et al., 1987) and the demonstration by monoclonal antibodies (mAbs) of $C$. pneumoniae species-specific antigens (Kuo et al., 1986).

Although $C$. pneumoniae is a common human respiratory pathogen (Grayston et al., 1989b; Marrie et al., 1987), very little is known about the immunochemistry of this organism. One problem is that $C$. pneumoniae is difficult to isolate in tissue culture. Immunochemical and genetic studies should lead to simple and non-culturedependent diagnostic methodologies for this important organism, as has been the case for $C$. trachomatis. Moreover, comparative studies of the nucleotide sequences of key $C$. pneumoniae antigens with other Chlamydia species might give insights into the evolutionary and structural diversity arising within this genus.

The chlamydial antigen for which the structure is best known is the major outer membrane protein (MOMP). MOMP is the most abundant protein at the surface of both the infectious EB and the intracellular replicative reticulate body (RB). Disulphide bridging between 
MOMP and other envelope proteins is considered important for maintaining the structural integrity of the infectious EB in the absence of cross-linking by peptidoglycan (Bavoil et al., 1984). Disulphide interlinking between MOMP polypeptide chains is thought to play an important role in regulating MOMP porin function, nutrient ingress through the EB outer envelope and ultimately the initiation of chlamydial differentiation itself (Bavoil et al., 1984). MOMP is an immunodominant antigen and antibodies to it form the basis of the serological classification of $C$. trachomatis (Stephens et al., 1982). Moreover, antibody to MOMP has been reported to neutralize chlamydial infection in vitro and in vivo (Zhang et al., 1987), making MOMP the principal candidate for the development of defined vaccines against $C$. trachomatis and $C$. psittaci and perhaps ultimately, C. pneumoniae.

Comparative analysis of deduced amino acid sequences for several $C$. trachomatis MOMPs shows that the protein has four variable sequences (VS 1-4) forming loops between five highly conserved regions. The serovar- and subspecies-specific epitopes, which have been associated with neutralization (Zhang et al., 1987), are located in VSs 1, 2 or 4 (Baehr et al., 1988; Conlan et al., 1988; Stephens et al., 1988). Nucleotide sequences have recently been published for the variable segments of 15 C. trachomatis serovars (Yuan et al., 1989). In addition, complete nucleotide sequences are available for the MOMP genes of a smaller number of $C$. trachomatis serovars (Baehr et al., 1988; Hamilton \& Malinowski, 1989; Hayes et al., 1990; Pickett et al., 1987; Stephens et al., 1986, 1987; Zhang et al., 1990) and for four strains of C. psittaci (Herring et al., 1989; Pickett et al., 1988; Zhang et al., 1989) but not for C. pneumoniae. This presumably reflects the difficulty of working with $C$. pneumoniae and the paucity of $C$. pneumoniae isolates now available.

We present here: (i) the complete nucleotide sequence of the MOMP gene of $C$. pneumoniae IOL-207; (ii) computer-derived phylogenetic maps of the evolutionary inter-relationships of MOMP nucleotide sequences in the genus Chlamydia; and (iii) a re-evaluation of the ultrastructural morphology of C. pneumoniae .

\section{Methods}

Bacterial strains and growth conditions. Chlamydia pneumoniae IOL207, isolated in 1967 from the conjunctiva of an Iranian child thought to be suffering from mild trachoma (Dwyer et al., 1972), was propagated in the yolk sacs of 6-8-d-old embryonated hens' eggs. The inoculated eggs were incubated at $\geq 66 \%$ relative humidity at $37^{\circ} \mathrm{C}$ and candled daily. Embryos were killed $20 \mathrm{~d}$ after infection by approved chilling at $-20^{\circ} \mathrm{C}$ for 1 h. C. pneumoniae ATCC VR 1310 (CDC/CWL 029) was originally isolated from the throat of a patient with pneumonia. This strain was obtained from the American Type Culture Collection and was grown in Buffalo Green Monkey Kidney (BGMK) cells (Flow Laboratories) in Dulbecco's Minimum Essential Medium (DMEM) supplemented with $1 \mu \mathrm{g}$ emetine hydrochloride $\mathrm{ml}^{-1}$ (Sigma). Escherichia coli strain JM109 [recAl endAl gyrA96 thi hsdr $17\left(\mathrm{r}_{\mathrm{k}}^{-} \mathrm{m}_{\mathrm{k}}^{+}\right.$supE44, relAl $\lambda^{-} \Delta$ (lac-pro $\left.A B\right),\left(\mathrm{F}^{\prime}\right.$, traD36 pro $A B$ lac $\left.\left.{ }^{\circ} \mathrm{Z} \Delta M 15\right)\right]$, carrying a Pst I-EcoRI insert in pUC9 coding for $\frac{3}{4}$ of the MOMP gene from $C$. trachomatis $\mathrm{L} 1 / 440 / \mathrm{LN}$, was grown in Luria-Bertani (LB) medium (Sambrook et al., 1989) containing $50 \mu \mathrm{g}$ ampicillin $\mathrm{ml}^{-1}$ (Sigma) or on plates of ampicillin supplemented LB with $1.5 \%$ (w/v) agar (Difco). $E$. coli strain Q358 ( $h s d \mathrm{r}_{\mathrm{k}}^{-} \mathrm{m}_{\mathrm{k}}^{+}$supF $\phi 80 \mathrm{r}$ ) was used as a host for $\lambda \mathrm{EMBL3}$ and was grown in either $\mathrm{TB}$ broth $(5 \mathrm{~g} \mathrm{NaCl}$ and $10 \mathrm{~g}$ Bacto-Tryptone per litre) supplemented with $0.2 \%(\mathrm{w} / \mathrm{v})$ maltose and $10 \mathrm{~mm}-\mathrm{MgSO}_{4}$, or on NZY (Sambrook et al., 1989) $1.5 \%$ (w/v) agar plates. Growth and amplification of phage in E. coli Q358 was in NZY $0.7 \%(w / v)$ agarose overlays upon NZY $1.5 \%(\mathrm{w} / \mathrm{v})$ agar plates. $E$. coli strain BB4, LE392.23, [ $\mathrm{F}^{\prime}$ lac $I^{9} \mathrm{Z} \Delta M 15$ proAB $\mathrm{Tn} 10\left(\right.$ tet $\left.\left.^{\mathrm{R}}\right)\right]$ obtained from Stratagene (Northumbria Biologicals) was used as the host for $\lambda$ ZAP II and was grown in either TB broth supplemented with $0.2 \%(\mathrm{w} / \mathrm{v})$ maltose, $10 \mathrm{mM}^{-\mathrm{MgSO}_{4}}$ and $15 \mu \mathrm{g}$ tetracycline $\mathrm{ml}^{-1}$ as recommended by the manufacturer; or on NZY tetracycline $1.5 \%(\mathrm{w} / \mathrm{v})$ agar plates. Growth and amplification of recombinant phage in $E$. coli BB4 was in NZY $0.7 \%(\mathrm{w} / \mathrm{v})$ agarose overlays upon NZY $1.5 \%(\mathrm{w} / \mathrm{v})$ agar plates. $E$. coli strain JM109 was grown either in TB broth supplemented with $0 \cdot 2 \%$ $(\mathrm{w} / \mathrm{v})$ maltose and $10 \mathrm{~mm}-\mathrm{MgSO}_{4}$ or on NZY $1.5 \%(\mathrm{w} / \mathrm{v})$ agar plates. $E$. coli JM109 cells carrying Bluescript SK( - ) recombinant plasmids were grown on LB $1.5 \%(\mathrm{w} / \mathrm{v})$ agar plates containing $50 \mu \mathrm{g}$ ampicillin $\mathrm{ml}^{-1}$.

Preparation of $C$. pneumoniae from infected yolk sacs. Embryonated eggs were used to overcome the difficulties associated with the bulk growth of $C$. pneumoniae in tissue culture. Yolk sacs were harvested aseptically and examined for the presence of chlamydial EBs. Four positive yolk sacs were suspended in Dulbecco's phosphate buffered saline (PBS) to give an approximate $20 \%(\mathrm{w} / \mathrm{v})$ suspension. This suspension was homogenized for $2 \mathrm{~min}$ in a Sorvall-Omnimix homogenizer and the resulting homogenate was centrifuged in a Sorvall HB4 rotor for $10 \mathrm{~min}$ at 1000 r.p.m. at $4{ }^{\circ} \mathrm{C}$. Eighteen millilitres of the middle layer was removed and centrifuged for $30 \mathrm{~min}$. at 18000 r.p.m. and $4{ }^{\circ} \mathrm{C}$ in a Sorvall SS34 swing-out rotor. Pellets were resuspended in $18 \mathrm{ml}$ PBS and dispersed by vortexing with glass beads, cooled on ice and briefly ultra-sonicated. The chlorofluorocarbon Arklone (ICI) was added to the suspension at a ratio of $1: 3$ and the mixture homogenized for $2 \mathrm{~min}$ on ice. The resulting emulsion was then centrifuged at 1000 r.p.m. in a Sorvall $\mathrm{HB} 4$ rotor for $5 \mathrm{~min}$ at $4{ }^{\circ} \mathrm{C}$. The upper white opalescent layer was removed and placed on ice whilst the sonication and extraction procedure was repeated on the residue. The final suspension was centrifuged at 1000 r.p.m. in a Sorvall HB4 rotor for 5 min at $4{ }^{\circ} \mathrm{C}$ and the upper opalescent layer was removed and frozen at $-20^{\circ} \mathrm{C}$.

Preparation and extraction of C. pneumoniae DNA. The EBs from the thawed suspension were pelleted by centrifugation, resuspended in $5 \mathrm{ml}$ of $0.2 \mathrm{M}$-sodium acetate, $\mathrm{pH} 6.9$ plus $10 \mathrm{mM}-\mathrm{MgSO}_{4}$ and dispersed by vortexing with glass beads. To this suspension 50-100 $\mu$ DNAase I $\left(9.5 \mathrm{mg} \mathrm{ml}^{-1}\right.$ ) (Sigma, molecular biology grade) was added and the mixture was incubated at $37^{\circ} \mathrm{C}$ for $1 \mathrm{~h}$ to digest remaining eukaryotic DNA. The reaction was stopped by the addition of EDTA to $50 \mathrm{~mm}$ and the EBs pelleted by centrifugation in a Sorvall SS34 rotor at 10000 r.p.m. at $4^{\circ} \mathrm{C}$ for $1 \mathrm{~h}$. The pellet was resuspended in $2 \mathrm{ml}$ saline Tris/EDTA (STE: $0.15 \mathrm{~m}-\mathrm{NaCl}, 10 \mathrm{~mm}$-Tris, pH 7.4, 1 mM-EDTA); RNAase A (Sigma, molecular biology grade) was added to $20 \mu \mathrm{g} \mathrm{ml}^{-1}$ and the mixture incubated at $37^{\circ} \mathrm{C}$ for $45 \mathrm{~min}$. The EBs were then repelleted and lysed in $5 \mathrm{ml}$ of $50 \mathrm{mM}-\mathrm{Tris} / \mathrm{HCl}, \mathrm{pH} \mathrm{7.5,20 \%}(\mathrm{w} / \mathrm{v})$ sucrose, $20 \mathrm{~mm}$-EDTA, $25 \mathrm{~mm}$-DTT, $1 \%$ (w/v) Sarkosyl and $200 \mu \mathrm{g}$ proteinase $\mathrm{K} \mathrm{ml}^{-1}$ at $55^{\circ} \mathrm{C}$ for $1-2 \mathrm{~h}$ or until clear. The nucleic acids 
were extracted with phenol/chloroform and the aqueous phase dialysed for $24 \mathrm{~h}$ against STE and stored at $4{ }^{\circ} \mathrm{C}$.

Enzymes and vectors. Restriction endonucleases, T4 DNA ligase, calf intestinal phosphatase and the digoxigenin DNA labelling kit were obtained from Boehringer Mannheim. rTaq DNA polymerase was obtained as AmpliTaq from Perkin Elmer Cetus. The $\lambda$ EMBL3 and undigested $\lambda$ ZAP II cloning kits and Gigapack II Gold packaging extract were obtained from Stratagene. Sequenase Version 2.0, containing the additional nucleotide analogue dITP, and 7-deazadGTP sequencing kits were obtained from United States Biochemical Corporation.

DNA probe production. (a) $5^{\prime}$ MOMP gene probe. Oligonucleotides were sythesized by $\beta$-cyanoethyl phosphoramidite chemistry on a model 381A automated DNA synthesizer (Applied Biosystems). Separate oligonucleotide primers starting at 57 bases upstream, $5^{\prime}$ CCGCCAGAAAAAGATAG $3^{\prime}$, on the coding strand and at 403 bases downstream, 5' ACATCAAAACGATCCCA $3^{\prime}$, on the complementary strand from the methionine start codon of the $C$. trachomatis L1/440/LN MOMP DNA sequence, plus rTaq DNA polymerase, digoxigenin nucleotide and a $C$. trachomatis $\mathrm{A} / \mathrm{SAl} / \mathrm{OT}$ genomic DNA template were used to prepare a labelled, $460 \mathrm{bp}$ polymerase chain reaction (PCR) product, using a Perkin Elmer Cetus DNA thermal cycler.

(b) 3' MOMP gene probe. A large-scale alkaline-lysed preparation of the recombinant plasmid pMP148 was purified (Sambrook et al., 1989). Following complete PstI and EcoRI digestion of the plasmid the $\simeq 1.5 \mathrm{~kb}$ insert was separated by agarose gel electrophoresis. The liberated fragment, containing 898 bp of the coding sequence of $C$. trachomatis $\mathrm{L} 1 / 440 / \mathrm{LN}$ MOMP, was excised from the gel, purified by Geneclean (Stratech Scientific) and labelled with digoxigenin.

Genomic library construction. Restriction endonuclease digests of the C. pneumoniae IOL-207 DNA were separated by gel electrophoresis. Fragments were transferred from the gel to Hybond-N nylon membrane (Amersham) and baked at $80^{\circ} \mathrm{C}$ for $90 \mathrm{~min}$. A single $8.5 \mathrm{~kb}$ $B g / I I$ fragment hybridized, at $65^{\circ} \mathrm{C}$ under standard conditions, with the digoxigenin-labelled PstI-EcoRI $3^{\prime}$ MOMP gene probe. Therefore, $B g / I I-$ digested DNA was ligated into BamHI-digested $\lambda E M B L 3$ and packaged using Gigapack II Gold with $E$. coli Q358 as host. Plaques were transferred to Hybond- $\mathrm{N}$ membranes, fixed, then hybridized with the PstI-EcoRI 3' MOMP probe.

$\lambda$ phage DNA production and cloning of the $C$. pneumoniae IOL-207 $M O M P$ gene into $\lambda Z A P$ II. Using $E$. coli $\mathrm{Q} 358$ as host, an amplified preparation of a single hybridizing recombinant plaque was used for the large-scale production (Sambrook et al., 1989) of $\lambda$ phage DNA. DNA was purified and concentrated with an Elutip-d Minicolumn from Schleicher \& Schüll (Anderman \& Co.) then digested with restriction endonucleases specific to the unique cloning sites of $\lambda \mathrm{ZAP}$ II. Using duplicate agarose gels, restriction fragments were separated, blotted and hybridized at $65^{\circ} \mathrm{C}$ with either the PCR-generated $5^{\prime}$ MOMP or the PstI-EcoRI 3' MOMP probe.

Hybridizing EcoRI fragments corresponding to the $5^{\prime}$ and $3^{\prime}$ ends of the $C$. pneumoniae MOMP gene were excised from a preparative agarose gel and purified by Geneclean. Each of these fragments was ligated into separate EcoRI-digested, dephosphorylated preparations of $\lambda$ ZAP II.

Separate preparations of $\lambda$ phage containing the $E c o$ RI fragments were packaged using Gigapack II Gold with E. coli BB4 as the host. Amplified preparations of recombinant plaques hybridizing with either the PCR or Pst $\mathrm{I}-E c o$ RI MOMP probes were made in E. coli BB4. Recombinant pBluescript SK(-) plasmids were prepared by in vivo excision with R408 helper phage. E. coli JM109 cells carrying
pBluescript SK $(-)$ recombinant plasmids were grown on LB $1.5 \%$ $(\mathrm{w} / \mathrm{v})$ agar plates containing $50 \mu \mathrm{g}$ ampicillin $\mathrm{ml}^{-1}$.

DNA sequencing. Large-scale preparations of the recombinant plasmids carrying EcoRI restriction fragments were extracted by alkaline lysis from E. coli JM109, and purified by chromatography on NACS-PREPAC columns (BRL). Templates were prepared (Zhang $e t$ $a l ., 1988)$ and sequenced by the dideoxynucleoside chain-termination method using $\left[\alpha^{-35}\right.$ S]dATP and modified T7 DNA polymerase (Sequenase). Nucleotide analogues dITP and 7-deaza-dGTP were used to resolve adjacent band compression areas.

Computer taxonomy. Nucleotide and inferred amino acid sequences of the MOMP of $C$. pneumoniae IOL-207 were compared with those of the other Chlamydia strains listed in Table 1, using PHYLIP version 3.2 computer software (Felsenstein, 1980). Programs used within PHYLIP were: the protein parsimony program PROTPARS; the DNA parsimony program DNAPARS and the program DNADIST, which computes the 'distance' between pairs of species from DNA sequences which are then utilized by the distance matrix programs FITCH and KITSCH. Sequences were first aligned with the multiple alignment program CLUSTAL (Higgins \& Sharp, 1988) so that they contained the same number of characters including padding characters. A small program was written to convert the CLUSTAL output into the format required for the PHYLIP programs. Alignment of the 15 protein sequences required 403 sequence positions (including padding characters); the 15 nucleotide sequences required 1220 residues. In general the sites of insertion of padding characters were similar for both protein and DNA sequences.

Electron microscopy. Infected cell monolayers on 24-well tissue culture trays were processed as previously described (Ward \& Murray, 1984). Briefly, infected cell monolayers in 24-well trays were fixed in glutaraldehyde, post-fixed in osmium tetroxide, stained with $1 \%(\mathrm{w} / \mathrm{v})$ aqueous uranyl acetate and dehydrated in a graded ethanol series. The intact cell sheet was then detached from the plastic substratum by brief treatment with 2-epoxy propane and flat-embedded in Spurr lowviscosity epoxy resin. After ultra-thin sectioning with a diamond knife, the preparations were examined in a Hitachi $\mathrm{H} 7000$ transmission electron microscope.

\section{Results}

\section{Molecular cloning of C. pneumoniae IOL-207 MOMP gene}

The $\simeq 1.5 \mathrm{~kb}$ fragment liberated from pMP148 by digestion with PstI and EcoRI was labelled with digoxigenin and used as a probe (Fig. 1, line $a$ ) for the $3^{\prime}$ region of the $C$. pneumoniae MOMP gene. The hybridization of digested $C$. pneumoniae IOL-207 DNA with the $3^{\prime}$ PstI-EcoRI probe suggested that the MOMP gene was most likely contained within an $8.5 \mathrm{~kb} B g / \mathrm{II}$ fragment (Fig. 2a). This fragment was therefore cloned into BamHI-digested $\lambda E M B L 3$ DNA. Successful cloning was confirmed by hybridization of the resulting plaques with the $3^{\prime}$ PstI-EcoRI probe. Digestion of the recombinant $\lambda$ phage DNA with various restriction endonucleases was followed by separate hybridizations with both the digoxigenin-labelled 3' PstI-EcoRI (Fig. 1, line a) and the 5' PCR-generated (Fig. 1, line $b$ ) probes. A $1.4 \mathrm{~kb}$ EcoRI fragment hybridized with the $3^{\prime} P s t \mathrm{I}-E c o$ RI probe 


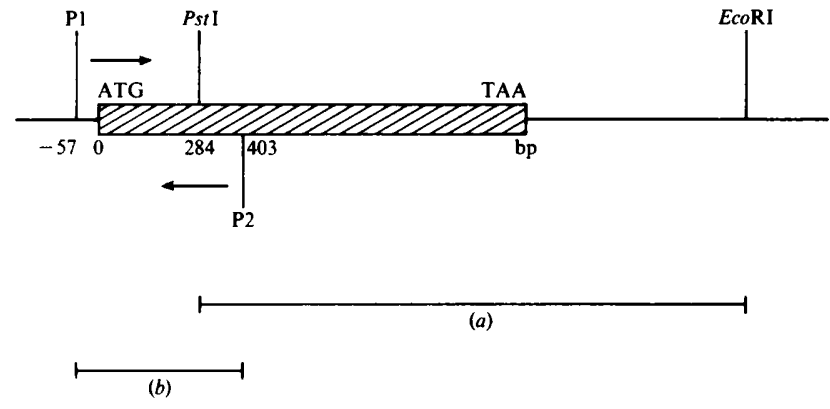

Fig. 1. Digoxigenin-labelled hybridization probes constructed from the MOMP genes of $C$. trachomatis: (a) $3^{\prime} 1.5 \mathrm{~kb}$ Pst I-EcoRI restriction fragment of $\mathrm{L} 1 / 440 / \mathrm{LN}$; (b) $5^{\prime} 460 \mathrm{bp}$ PCR-synthesized fragment of A/SAl/OT. The hatched box marks the position of the complete MOMP gene. P1, primer 1; P2, primer 2.

(Fig. 2b, panel B) and a $3.3 \mathrm{~kb}$ fragment hybridized with both probes (Fig. $2 b$, Panels A and B). This suggested that these two restriction fragments carried the whole MOMP gene between them; the $3.3 \mathrm{~kb}$ fragment containing the region bounded by the $5^{\prime}$ start codon and the EcoRI site, whilst the $1.4 \mathrm{~kb}$ fragment contained the region between the EcoRI site and the $3^{\prime}$ stop codon. These two restriction fragments were therefore subcloned into separate EcoRI-digested, dephosphorylated preparations of $\lambda$ ZAP II. Successful cloning of the two EcoRI inserts was confirmed by hybridization of their respective plaques in E. coli BB4 with either the $3^{\prime}$ Pst I$E c o$ RI or the $5^{\prime}$ PCR-generated probe. $\lambda$ ZAP II recombinants were then converted to pBluescript SK $(-)$ plasmids using R408 helper phage.

\section{The C. pneumoniae IOL-207 MOMP gene sequence}

Plasmids carrying the 1.4 and $3.3 \mathrm{~kb}$ EcoRI inserts were purified and used as templates for DNA sequencing. Forward Universal primer, used in the first sequencing reactions of both plasmid templates, provided open reading frames (ORFs) of the MOMP gene. Alignments were found between the translated product of the ORFs of both inserts and the MOMP gene sequence of $C$. trachomatis L1. Orientation of the aligned inserts confirmed that the $5^{\prime}$ and $3^{\prime}$ regions of the $C$. pneumoniae IOL-207 MOMP gene were contained within the 3.3 and the $1.4 \mathrm{~kb}$ fragments, respectively. Both strands of the $C$. pneumoniae IOL-207 MOMP gene were then sequenced, giving an ORF of $1167 \mathrm{bp}$ (389 amino acids). This sequence is shown in Fig. 3. A conserved $\mathrm{XbaI}$ restriction site was then used to align and compare the restriction maps of the MOMP genes of C. pneumoniae IOL-207 and C. trachomatis serovar L1 (Fig. 4).
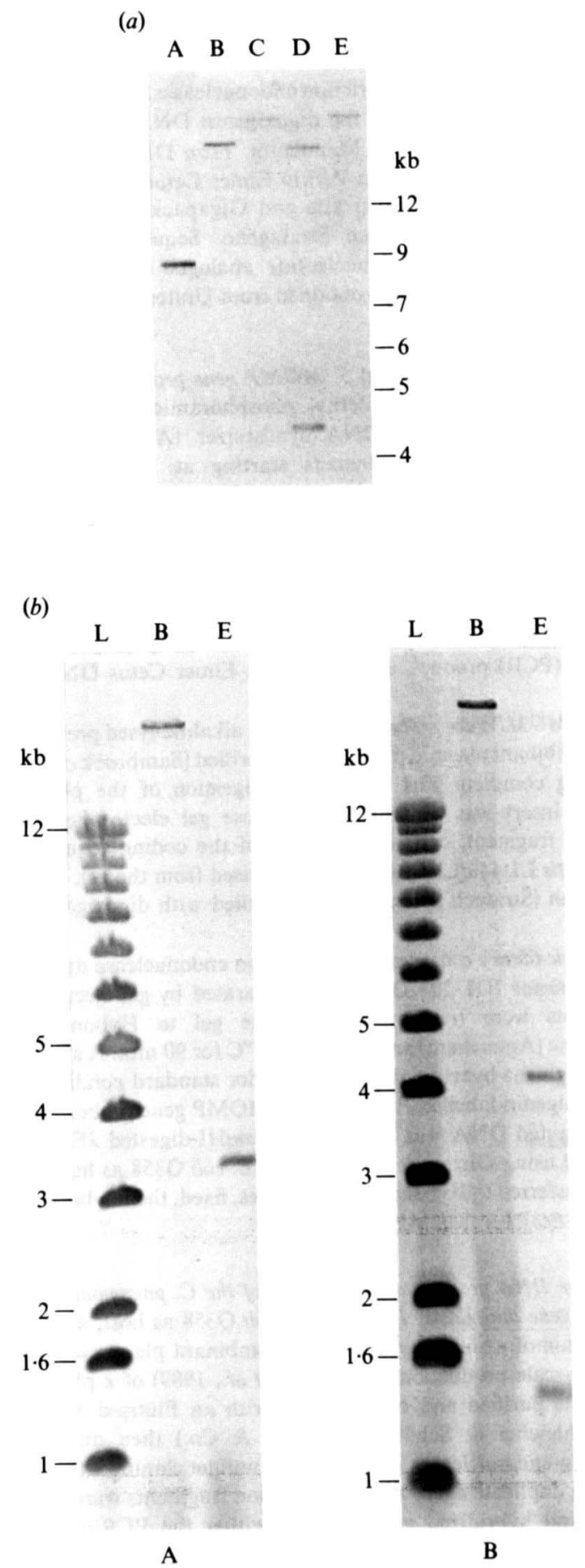

Fig. 2. Southern blots of $C$. pneumoniae IOL-207 DNA. (a) Genomic DNA was digested with restriction endonucleases (A, BgIII; B, SacI; C, SalI ; D, XhoI ; E, SpeI), separated by agarose gel electrophoresis, Southern blotted and probed with the digoxigenin-labelled 3'Pst IEcoRI MOMP gene probe. (b) Recombinant $\lambda$ EMBL3 DNA digested with restriction endonucleases (B, Bg/II; E, EcoRI), separated, Southern blotted and probed with either (panel A) digoxigenin-labelled 5' PCR-synthesized MOMP gene probe or (panel B) 3' PstI-EcoRI MOMP gene probe. Tracks labelled $\mathrm{L}$ contain a digoxigenin-labelled $1 \mathrm{~kb}$ ladder. 

15
30
45
60
$+75$
90
105

ATG AAA AAA CTC TTA AAG ICG GCG TTA TIA TCC GCC GCA ITT GCT GGT TCT GTC GGC TCC ITA CAA GCC TIG CCT GTA GGG AAC CCT TCT GAT CCA AGC TIA TIA AIT GAT GGT ACA Met Lys Lys Leu Leu Lys Ser Ala Leu Leu Ser Ala Ala Phe Ala Gly Ser Val Gly Ser Leu Gln Ala Leu Pro Val Gly Asn Pro Ser Asp Pro Ser Leu Leu Ile Asp Gly Thr

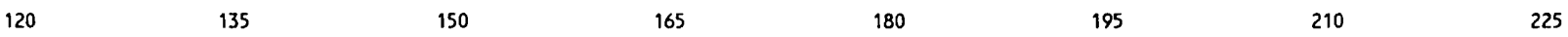

ATA TGG GAG GGT GCT GCA GGA GAT CCT TGC GAT CCT TGC GCT ACT TGG TGC GAC GCT ATT AGC TTA CGI GCT GGA TTT TAC GGA GAC TAT GTT TIC GAC CGT ATC TTA AAA GTA GAT Ile Trp Glu Gly Ala Ala Gly Asp Pro Cys Asp Pro Cys Ala Thr trp Cys Asp Ala lle Ser Leu Arg Ala Gly Phe Tyr Gly Asp tyr Val Phe Asp Arg Ile Leu Lys Val Asp

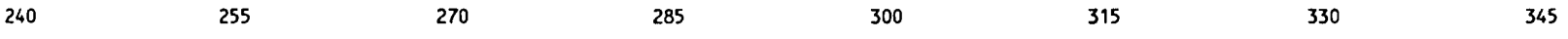

GCA CCT AAA ACA ITI TCT ATG GGA GCC AAG CCT ACT GGA TCC GCT GCT GCA AAC TAT ACT ACT GCC GTA GAT AGA CCT AAC CCG GCC TAC AAT AAG CAT TIA CAC GAT GCA GAG TGG Ala Pro Lys Thr Phe Ser Met Gly Ala Lys Pro Thr Gly Ser Ala Ala Ala Asn Tyr Thr Thr Ala Val Asp Arg Pro Asn Pro Ala Tyr Asn Lys His Leu His Asp Ala Glu Trp

$\begin{array}{llllll}360 & 375 & 390 & 405 & 420 & 435\end{array}$ ITC ACT AAT GCA GGC ITC ATT GCC TTA AAC ATT TGG GAT CGC TTT GAT GTT TIC TGT ACT TTA GGA GCT TCT AAT GGT IAC ATT AGA GGA AAC TCT ACA GCG TTC AAT CTC GIT GGT Phe thr Asn Ala Gly Phe lle Ala Leu Asn Ile Irp Asp Arg phe Asp Val Phe Cys Thr Leu Gly Ala Ser Asn Gly Iyr Ile Arg Gly Asn Ser thr Ala Phe Asn Leu Val Gly

495 510 525 540 555 570

585 TTA TIC GGA GTT AAA GGT ACT ACT GTA AAT GCA AAT GAA CTA CCA AAC GTT TCT TTA AGT AAC GGA GTT GTT GAA CTT TAC ACA GAC ACC TCT TTC ICT TGG AGC GTA GGC GCT CGT Leu Phe Gly Val Lys Gly Thr Thr Val Asn Ala Asn Glu Leu Pro Asn Val Ser Leu Ser Asn Gly Val Val Glu Leu Tyr Thr Asp Thr Ser Phe Ser Trp Ser Val Gly Ala Arg 615 645 660 675 690 GGA GCC ITA TGG GAA TGC GGT TGT GCA ACT ITG GGA GCT GAA TIC CAA TAT GCA CAG TCC AAA CCT AAA GTT GAA GAA CIT AAT GTG ATC TGT AAC GTA TCG CAA ITC TCT GTA AAC Gly Ala Leu Trp Glu Cys Gly Cys Ala thr Leu Gly Ala Glu Phe GIn tyr Ala Gln Ser Lys pro lys Val Glu Glu Leu Asn Val Ile Cys Asn Val Ser GIn Phe Ser Val Asn $\begin{array}{llllll}705 & 720 & 735 & 750 & 765 & 780\end{array}$ AAA CCC AAG GGC TAT AAA GGC GIT GCT ITC CCC TIG CCA ACA GAC GCT GGC GTA GCA ACA GCT ACT GGA ACA AAG TCT GCG ACC ATC AAT TAT CAT GAA TGG CAA GTA GGA GCC TCT Lys Pro Lys Gly Tyr Lys Gly Val Ala Phe Pro Leu Pro thr Asp Ala Gly Val ala thr Ala thr Gly thr Lys Ser Ala thr Ile Asn tyr his Glu Trp Gln Val Gly Ala Ser

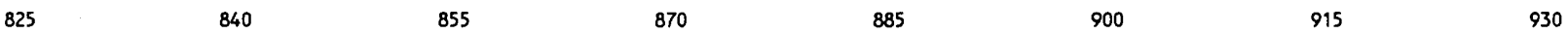
CTA TCT TAC AGA CTA AAC ICT ITA GTG CCA TAC ATT GGA GTA CAA TGG TCT CGA GCA ACT TIT GAT GCT GAT AAC ATC CGC ATT GCT CAG CCA AAA CTA CCT ACA GCT GTT ITA AAC Leu Ser Tyr Arg Leu Asn Ser Leu Val Pro Tyr Ile Gly Val Gln Trp Ser Arg Ala Thr Phe Asp Ala Asp Asn Ile Arg Ile Ala Gln Pro Lys Leu Pro thr Ala Val Leu Asn

945

960975

990

1005

1020

1035

1050

ITA ACT GCA TGG AAC CCT TCT TIA CTA GGA AAT GCC ACA GCA TTG TCT ACT ACT GAT TCG ITC TCA GAC TIC ATG CAA ATT GTT TCC TGT CAG ATC AAC AAG TIT AAA TCT AGA AAA Leu Thr Ala Irp Asn Pro Ser Leu Leu Gly Asn Ala Thr Ala Leu Ser Thr Thr Asp Ser Phe Ser Asp Phe Met Gln Ile Val Ser Cys Gln Ile Asn Lys Phe Lys Ser Arg Lys

$\begin{array}{llllll}1065 & 1080 & 1095 & 1110 & 1125 & 1140\end{array}$ GCT TGT GGA GIT ACT GIA GGA GCT ACT TTA GTI GAT GCT GAT AAA TGG TCA CTT ACT GCA GAA GCT CGT TIA ATT AAC GAG AGA GCT GCT CAC GTA TCT GGT CAG TTC AGA TIC TAA Ala Cys Gly Val thr Val Gly Ala thr Leu Val Asp Ala Asp lys trp Ser leu thr Ala glu Ala arg Leu Ile Asn Glu Arg Ala Ala his Val Ser Gly gln Phe Arg Phe *

Fig. 3. Nucleotide and inferred amino acid sequence of the open reading frame of the MOMP gene of $C$. pneumoniae IOL-207. The cleavage site of the signal peptide is indicated by an arrow. The underlined nucleotide sequence indicates the EcoRI restriction site.
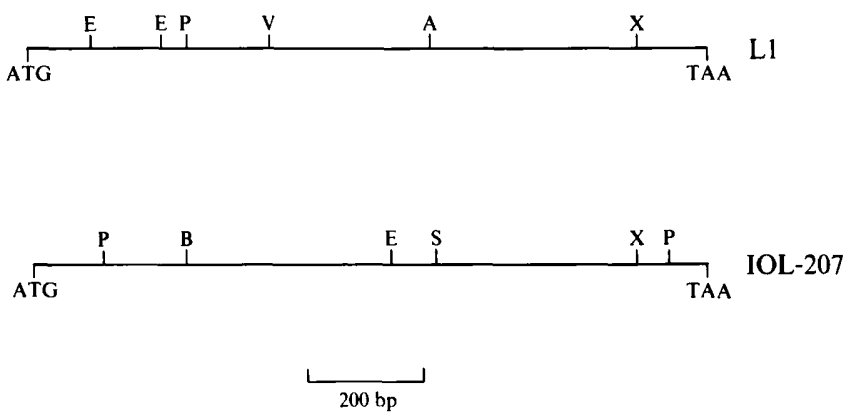

Fig. 4. Restriction endonuclease maps of the MOMP genes of $C$. pneumoniae IOL-207 and C. trachomatis L1/440/LN. E, EcoRI ; P, PstI; V, EcoRV; A, AsnI; X, XbaI; B, BamHI; S, StyI.

\section{Amino acid sequence}

The deduced amino acid sequences of the MOMP gene of $C$. pneumoniae IOL-207 and of 10 strains representing six serovars of $C$. trachomatis and four strains of $C$. psittaci (Table 1) were aligned. For clarity, Fig. 5 shows the alignments of the MOMP gene sequences for only $C$. pneumoniae, $C$. trachomatis A/SA1/OT, B/Jali20/OT and $\mathrm{Ll} / 440 / \mathrm{LN}, C$. psittaci ovine abortion agent A22/M and guinea pig inclusion conjunctivitis strain 1 . The signal peptide of $C$. pneumoniae MOMP consisted of 23 amino acids in contrast to the 22 amino acids of the other Chlamydiae. Homology with other amino acid sequences in the signal peptide was 15/23 (C. trachomatis), 16/23 (C. psittaci A22/M) and 15/23 (C. psittaci GPIC). Fig. 5 also shows the characteristic four variable regions of MOMP for $C$. pneumoniae. Cysteine residues are considered crucial for MOMP porin function; $C$. pneumoniae and all other chlamydial MOMP sequences, with the exception of B/TW5/OT (Stephens et al., 1987), contained seven conserved cysteine residues. C. pneumoniae had a unique cysteine residue at position 333 and there was an additional cysteine at position 212 which was also present in C. trachomatis but not C. psittaci (Fig 5). Overall, there was $67 \cdot 2-67.9 \%$ homology between the $C$. pneumoniae MOMP nucleotide sequence and $C$. trachomatis sequences and $71 \cdot 5-72 \cdot 4 \%$ homology with the $C$. psittaci sequences (Table 1). 
Table 1. Nucleotide and amino acid homology of the MOMP gene of C. pneumoniae IOL-207 with strains of C. trachomatis and C. psittaci

\begin{tabular}{|c|c|c|c|c|c|}
\hline \multirow[b]{2}{*}{ Species } & \multirow[b]{2}{*}{ Serovar } & \multirow[b]{2}{*}{ Strain } & \multicolumn{2}{|c|}{ Percentage homology } & \multirow[b]{2}{*}{ Reference of strain } \\
\hline & & & Nucleotide & Amino acid & \\
\hline \multirow[t]{10}{*}{ C. trachomatis } & A & A/Harl3/OT & $67 \cdot 2$ & $63 \cdot 5$ & Baehr et al. (1988) $\dagger$ \\
\hline & A & $\mathrm{A} / \mathrm{SAl} / \mathrm{OT}$ & $67 \cdot 3$ & $64 \cdot 7$ & Hayes et al. (1990) \\
\hline & B & B/TW5/OT & $67 \cdot 6$ & $64 \cdot 1$ & Baehr et al. (1988) $\dagger$ \\
\hline & $\mathbf{B}$ & B/TW5/OT & $67 \cdot 4$ & $63 \cdot 8$ & Stephens et al. (1987) \\
\hline & B & B/Jali20/OT & 67.9 & $64 \cdot 3$ & Hayes et al. (1990) \\
\hline & $\mathrm{C}$ & C/TW3/OT & $67 \cdot 5$ & $64 \cdot 1$ & Stephens et al. (1987) \\
\hline & $\mathbf{F}$ & IC-Cal-3 & $67 \cdot 4$ & $63 \cdot 6$ & Zhang et al. (1990) \\
\hline & $\mathbf{H}$ & $*$ & 67.9 & $65 \cdot 1$ & Hamilton \& Malinowski (1989) \\
\hline & $\mathbf{L} 1$ & $\mathrm{Ll} / 440 / \mathrm{LN}$ & $67 \cdot 6$ & $64 \cdot 2$ & Pickett et al. (1987) \\
\hline & L2 & $\mathrm{L} 2 / 434 / \mathrm{Bu}$ & $67 \cdot 4$ & $64 \cdot 1$ & Stephens et al. (1986) \\
\hline \multirow[t]{4}{*}{ C. psittaci } & & $\mathrm{A} 22 / \mathrm{M}$ & $71 \cdot 8$ & $70 \cdot 2$ & Pickett et al. (1988) \\
\hline & & $\mathrm{S} 26 / 3$ & $72 \cdot 4$ & $75 \cdot 9$ & Herring et al. (1989) \\
\hline & & GPIC 1 & $72 \cdot 1$ & 73.9 & Zhang et al. (1989) \\
\hline & & $\mathrm{Mn}-\mathrm{Cal}-10$ & $71 \cdot 5$ & $70 \cdot 2$ & Zhang et al. (1989) \\
\hline C. pneumoniae & & IOL-207 & $100 \cdot 0$ & $100 \cdot 0$ & \\
\hline
\end{tabular}

* Strain unknown. † Personal communication.

$60 \quad 70 \quad 80$

MKKLLKSALLSAAFA-GSVGSLQALPVGMPSDPSLLIDG INEGAAGDP|C|OP|C|ATW|C|DAISLRAGFYGOYVFDRILKVOAPK|TFS-MGAKPTGSAAANYTT----AV|DRPNPAYMKHLHDAEWFTMAGF IALNIWDRFOVF /C |TLGASMGYI

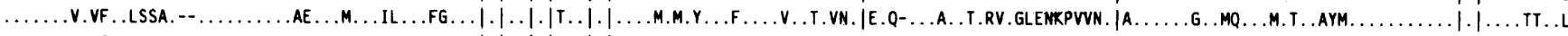

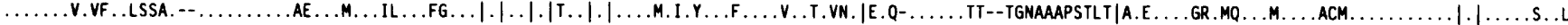

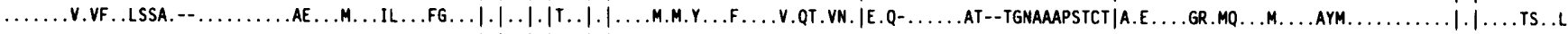

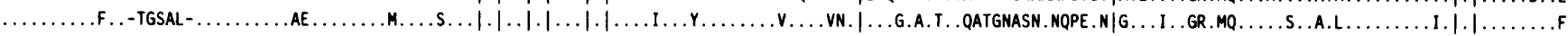

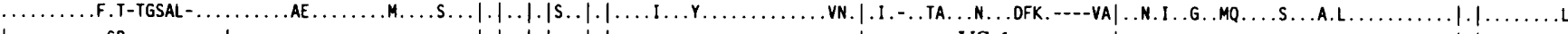
SP ........................ VS 1

$\begin{array}{lllllllllllllll}130 & 140 & 150 & 160 & 170 & 180 & 190 & 200 & 210 & 220 & 230 & 240 & 250 & 260 & 270\end{array}$

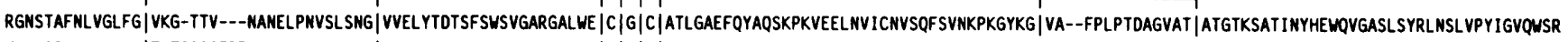

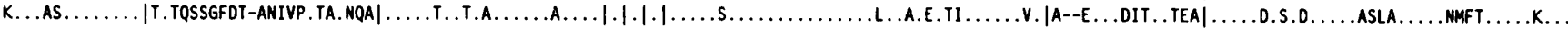

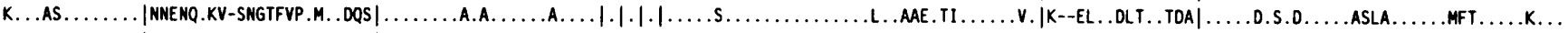

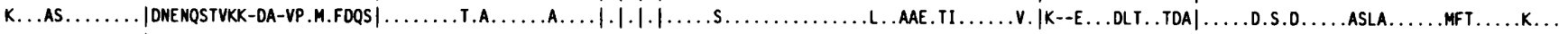

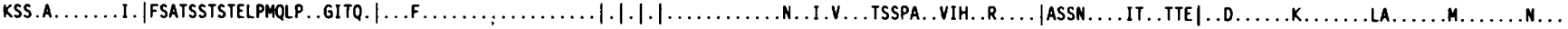

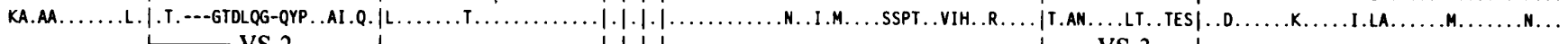
VS 2

$\begin{array}{lllllllll}300 & 310 & 320 & 330 & 340 & 350 & 360 & 370 & 380\end{array}$

ATFDADNIRIAQPK |LPTAVLML TAMNPSLLGMATALSTT---DSFSDFM|OIVSCQIMKFKSRKA |C G GVTVGATLVDADKWSLTAEARLINERAAHVSGQFRF

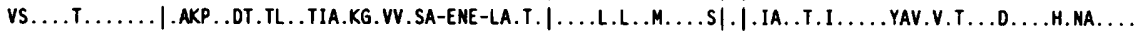

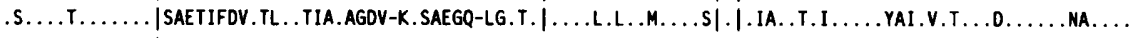

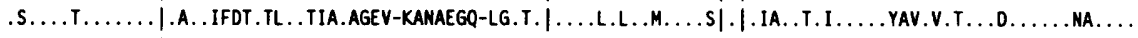

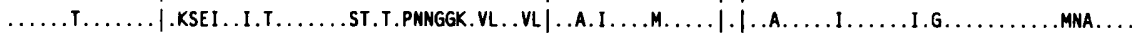

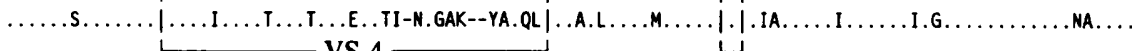

$\begin{array}{ll}\text { C. pneumoniae } & \text { IOL-207 } \\ \text { C. trachomatis } & \text { A/SA1/OT } \\ & \text { B/Jali20/OT } \\ & \text { L1/440/LN } \\ \text { C. psittaci } & \text { A22/M } \\ & \text { GPIC } 1\end{array}$

Fig. 5. Comparative alignment of the amino acid sequence of the MOMP gene of $C$. pneumoniae IOL-207 with the MOMP genes of $C$. trachomatis A/SA1/OT; B/Jali 20/OT; L1/440/LN, C. psittaci ovine abortion agent A22/M and guinea pig inclusion conjunctivitis strain 1 (GPIC 1). Dots indicate identity and dashes indicate deletions. Conserved cysteine residues and VS $1-4$ are boxed. The signal peptide is marked as SP. Numbers refer to C. pneumoniae IOL-207 MOMP. 
C. psittaci

C. pneumoniae

$$
\text { C complex }
$$

C. trachomatis

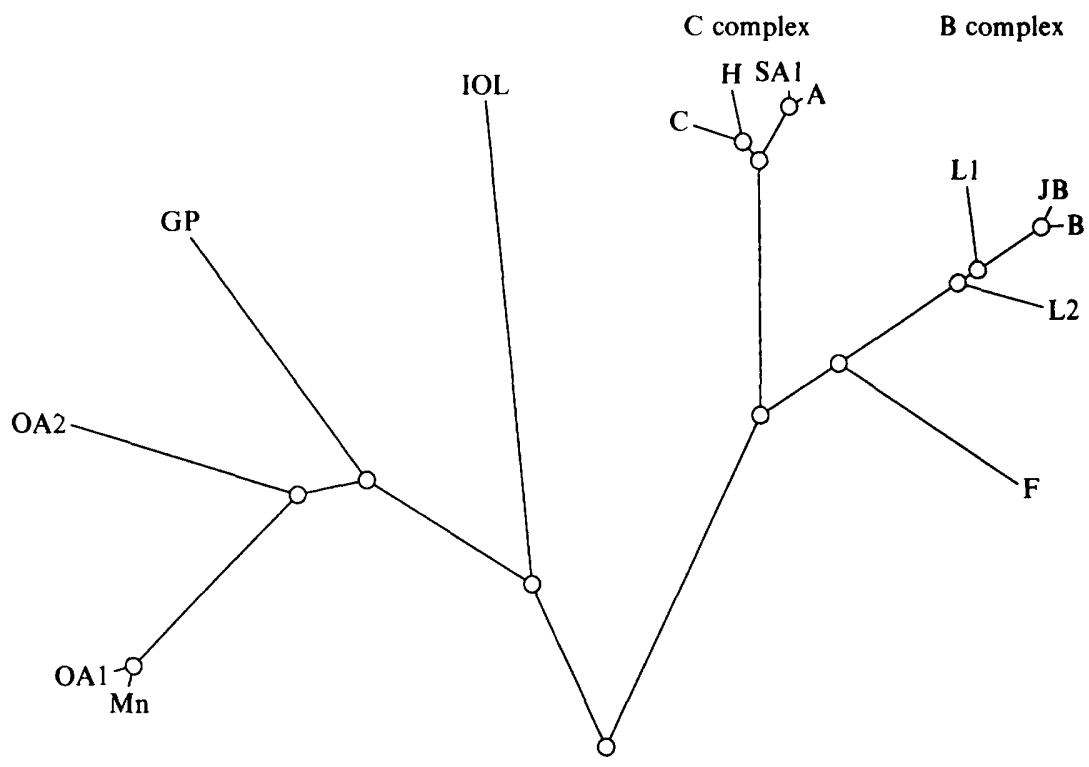

Fig. 6. The rooted tree obtained by computer taxonomy for 14 nucleotide sequences coding for the MOMP genes of $C$. psittaci: meningopneumonitis Cal $10(\mathrm{Mn})$; ovine abortion A22/M (OA1); ovine abortion strain $\mathrm{S} 26 / 3$ (OA2); guinea pig inclusion conjunctivitis strain 1 (GP); $C$. pneumoniae IOL-207 (IOL); C. trachomatis: C/TW3/OT (C); serovar $\mathrm{H}$ strain unknown (H); A/SAl/OT (SAl); A/Har13/OT (A); L2/434/Bu (L2); B/TW5/OT (B); B/Jali 20/OT (JB); L1/440/LN (L1); F/IC-Cal-3/GU (F). In this figure the length of the lines connecting nodes is proportional to the relative evolutionary time between each of them.

\section{Phylogenetic classification}

When protein and DNA sequences are used to develop a phylogenic relationship the initial result is an unrooted tree, i.e. a tree where the branching order, intermediate nodes and the relative distances between each node have been identified but where the ancestral node (the root of the tree) has not been identified. In order to identify the root, additional assumptions must be made. Usually it is sufficient to assume that there is a constant evolutionary clock which affects all sequences equally. Protein parsimony studies in which the order of presentation of the complete protein sequences was randomized always gave the same results: an unrooted tree with three minor variations in one location. These variations arose through the uncertainty of determining whether there are one or two intermediate nodes between the sequences for the MOMPs of serovars $\mathrm{H}$ and $\mathrm{C}$.

More detailed studies were conducted using the nucleotide data as it is possible to estimate the relationships (distance) between nucleotide sequences with less ambiguity than for amino acid sequences. The program DNAPARS confirmed that the unrooted trees obtained using the nucleotide sequences were equivalent to those obtained using the protein sequences. Two trees were identified, again differing as to whether there are one or two intermediate nodes between the MOMPs of C. trachomatis serovars $\mathrm{H}$ and $\mathrm{C}$.

In order to produce a rooted tree, the program DNADIST was used to calculate the distances between each pair of DNA sequences. The Kimura '2-parameter' model (Kimura, 1980) was used; this allows a difference between transition and transversion rates. Unfortunately, this program could not be used for all 15 sequences, as two of the $C$. trachomatis serovar B sequences had only four nucleotide differences between them; this degree of similarity caused a numerical error condition and the program DNADIST terminated prematurely. However, removing one of these sequences permitted calculation of the distance matrix for the remaining 14 sequences. The program KITSCH, which employs a Fitch-Margoliash least-squares approach, was used to identify a single rooted tree. KITSCH assumes that the sequences available were all obtained at the same relative evolutionary time from the origin (i.e. that they are all present-day isolates). This implies, therefore, since there is also an assumption of a constant evolutionary clock, that the distance from the root to each tip representing an extant species must be the same. With these assumptions a rooted tree was obtained (Fig. 6).

\section{Electron microscopy}

One of the taxonomic criteria suggested for $C$. pneumoniae is the presence of pear-shaped EBs (Grayston et al., $1989 a$; Kuo et al., 1988). However, we have also observed occasional aberrant pear-shaped EBs in preparations of $C$. trachomatis and $C$. psittaci and were thus concerned to establish whether pear-shaped EBs are a reliable characteristic of all $C$. pneumoniae strains. Figs $7(a)$ and $7(b)$ are transmission electron micrographs of $C$. pneumoniae strains IOL-207 and ATCC VR 1310 respectively. Representative $C$. trachomatis and $C$. psittaci strains whose ultrastructural morphology is well 

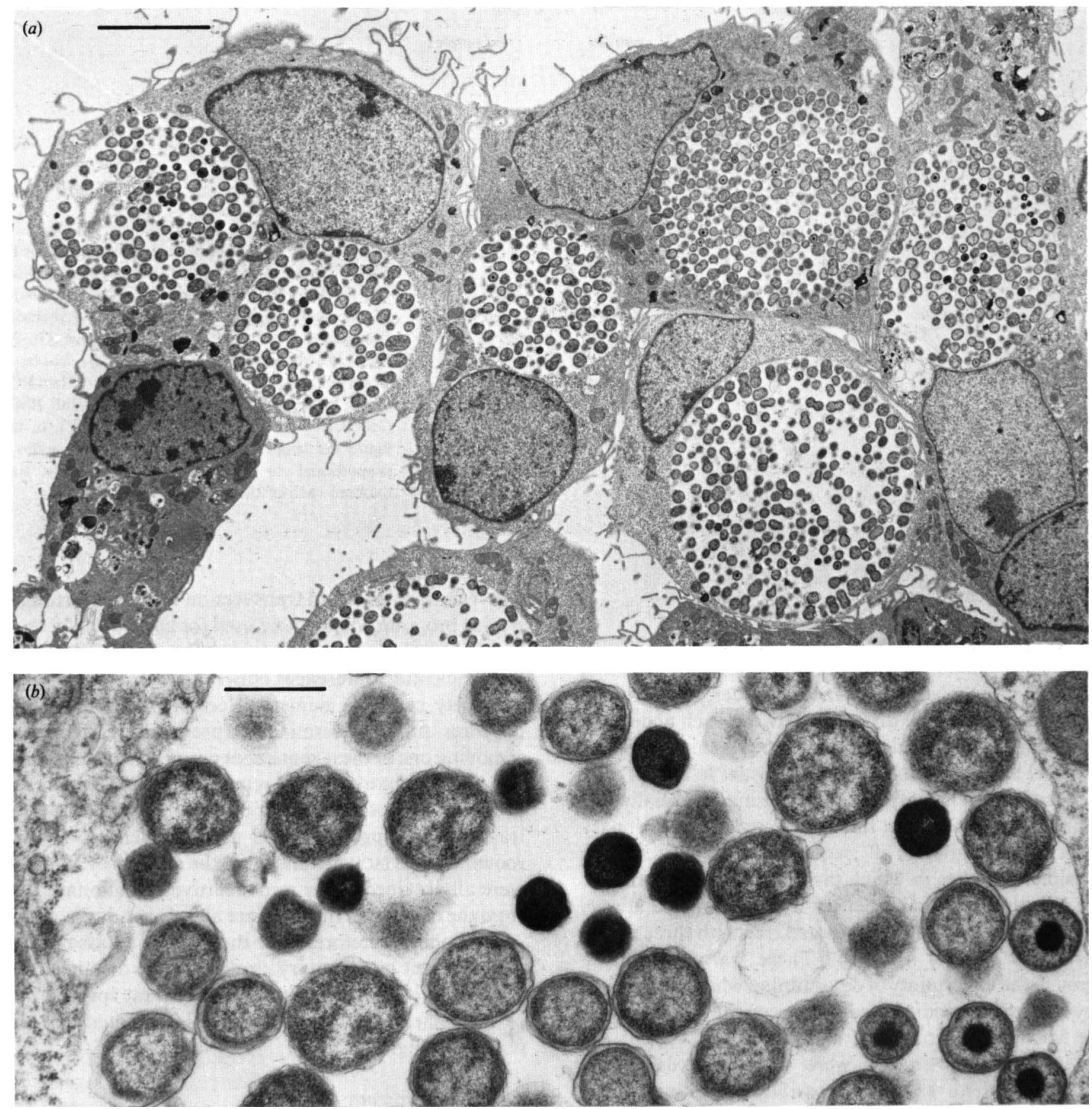

Fig 7. Transmission electron micrographs of $C$. pneumoniae in tissue culture. (a) Low-power picture of IOL-207 in BGMK cells. The EBs appear as small dark dots within the inclusions. Note the relatively small number of infectious EBs despite the maturity of the inclusions. Bar, $5 \mu \mathrm{m}$. (b) ATCC VR 1310. Higher magnification picture to show the morphology of the EBs. The EBs of both $C$. pneumoniae strains were round, occasionally crenellated but rarely pear-shaped. These EBs could not reliably be distinguished from EBs of $C$. trachomatis or $C$. psittaci in material processed in parallel. Bar, $0.5 \mu \mathrm{m}$.

known were also processed in parallel (data not shown) as a control for possible fixation artifacts. Fig. 7(a) shows that excellent growth of $C$. pneumoniae was achieved in BGMK cells treated with $1 \mu \mathrm{g}$ emetine $\mathrm{ml}^{-1}$. However, although large mature inclusions were obtained, remar- kably few infectious EBs were present. Those $C$. pneumoniae EBs which were observed were round rather than pear-shaped (Fig. $7 b$ ), occasionally crenellate, and could not reliably be distinguished from EBs of $C$. trachomatis or $C$. psittaci. 


\section{Discussion}

Strains of C. pneumoniae were formerly known as TWAR agents, an acronym derived from the fact that the first isolate was from Taiwan and that subsequent isolates were associated with acute respiratory infection (Grayston et al., 1986). Species designation was attained as recently as 1989 (Grayston et al., 1989a). The type strain, TW 183, was not available to us at the commencement of this study. We therefore chose to work with IOL-207, the second known C. pneumoniae isolate (Dwyer et al., 1972; Grayston et al., 1989b). Both strains were originally isolated from the conjunctivae of children in trachomaendemic areas; TW 183 was isolated in Taiwan in 1965 whilst IOL-207 was isolated in London from an Iranian child with mild trachoma in 1967. Both organisms share the same fastidious growth characteristic of $C$. pneumoniae (Grayston et al., 1989b). In 1972 TW 183 and IOL-207 were found to be immunologically identical using a twoway micro-immunofluorescence (micro-IF) typing test (Dwyer et al., 1972). During the course of this study a $C$. pneumoniae strain was deposited by $\mathrm{CDC}$ in the American Type Culture Collection (ATCC VR 1310) and thus became available to us. mAb to IOL-207 reacts with TW 183 in the micro-IF test (J. D. Treharne, unpublished observation) and with ATCC VR 1310 on dot blot. Conversely, C. pneumoniae-specific $\mathrm{mAb}$ to TW 183 also reacts on micro-IF with IOL-207 (J. D. Treharne, unpublished observation) and with ATCC VR 1310 (Carolyn Black, CDC, personal communication). Neither of these mAbs reacts with $C$. psittaci or $C$. trachomatis. We have also sequenced the gene for the $60 \mathrm{kDa}$ cysteine-rich, outer membrane protein of IOL207; oligonucleotide probes derived from this sequence reacted in a species-specific manner in the PCR reaction with genomic DNA from C. pneumoniae ATCC VR 1310 (M. W. Watson and others, unpublished observations). Finally our computer study (see below) confirmed that the IOL-207 MOMP sequence is taxonomically distinct from known MOMP sequences for $C$. trachomatis or $C$. psittaci. The eclectic association of the above findings would suggest that there can be little doubt that IOL-207 is a genuine $C$. pneumoniae isolate.

The MOMP gene of $C$. pneumoniae shows all the characteristics of a chlamydial MOMP. The signal peptides for MOMP in all three species of Chlamydia are virtually identical, with a classic Leu-Glu-Ala protease cleavage site. The $C$. pneumoniae signal peptide has 23 rather than 22 amino acids and there are a few minor substitutions for amino acids of similar properties. The N-terminus of the MOMP for all three species is also similar, with the first six amino acids identical (LPVGNP). We speculate that this region of the protein is conserved in order to ensure correct anchorage in the membrane. The other conserved feature between the MOMP sequences is the position of seven conserved cysteine residues, which are probably important in the structural and functional role of this protein.

The four variable regions of MOMP are of major interest for vaccine development (Taylor-Robinson \& Ward, 1989) and are also present in C. pneumoniae. VS 1 , 2 and 4 of $C$. trachomatis are of particular interest because they are hydrophilic, have high beta turn potential, and are thought to form loops at the surface of chlamydial EBs accessible to neutralizing serovar- or subspecies-specific antibodies (Zhang et al., 1987). VS 2 and VS 4 are topographically juxtaposed on the chlamydial surface, forming a discontinuous epitope which can be spanned by a single mAb paratope (Conlan et al., 1990). Both these exposed loops may function in a co-ordinated manner to promote chlamydial adhesion (Su et al., 1990). VS 1 of the C complex of C. trachomatis contains immunodominant subspecies- and type-specific epitopes (Baehr et al., 1988; Stephens et al., 1988) whose critical binding sites, in the case of A/SAl/OT, have been localized to the peptides VAGL and EKD respectively (Hayes et al., 1990). As might be expected, there are no analogous peptides to these in the VS 1 of $C$. pneumoniae. In the B complex of $C$. trachomatis, by contrast, it is VS 2 which so far appears to contain the dominant type epitope (Baehr et al., 1988; Conlan et al., 1988; Stephens et al., 1988). In particular in C. trachomatis $\mathrm{B} / \mathrm{Jali} 20 / \mathrm{OT}$ and $\mathrm{L} 1 / 440 / \mathrm{LN}$ the critical binding sites for type-specific antibody are the peptides GTFVP and DA-VP (Conlan et al., 1988; Hayes et al., 1990). Interestingly, in all known chlamydial MOMP sequences there are two or three variable amino acids followed by a hydrophobic amino acid ( $\mathrm{L}, \mathrm{Y}$ or $\mathrm{V}$ ) and proline, a computer-predicted turn-generating amino acid. We speculate that the unique peptide ANELP in the equivalent position in $C$. pneumoniae MOMP is also surface exposed and this may represent a type-specific region. In VS 4 of the $B$ complex serovars of $C$. trachomatis there are two known subspecies- and one species-specific epitope (Baehr et al., 1988; Conlan et al., 1988, 1989). We are unable to identify a clear counterpart in C. pneumoniae.

Chlamydiae have no other porin proteins and therefore MOMP is presumed essential for chlamydial survival. From a taxonomic viewpoint MOMP is in many ways an ideal protein to study; there must inevitably be large regions of structure which have been conserved throughout evolution. However, there are also immunodominant variable regions which, at least for $C$. trachomatis, can be related to the serological classification and which are also epidemiologically associated with different patterns of clinical disease. Moreover, with the publication of the $C$. pneumoniae sequence, there 
are now considerable data on MOMP gene structure for all Chlamydia species.

Computer taxonomy provides an objective method of applying generalized taxonomic criteria to the particular problem of evolutionary relationships amongst Chlamydiae; the program which we used was developed for plant taxonomy (Felsenstein, 1980). The same classification tree resulted irrespective of whether we used nucleotide or inferred amino acid sequence data. This implies that there are no dramatic differences in codon preference amongst the Chlamydiae. Hybridization studies using whole genomic DNA found less than $10 \%$ homology between $C$. pneumoniae and the other two chlamydial species (Cox et al., 1988). This led to the suggestion that the chlamydial species might be an example of convergent evolution from divergent ancestors. This has never seemed to us a convincing argument given the uniqueness of the genus Chlamydia; it is certainly not supported by the high degree of homology amongst the chlamydial MOMP genes. Comparisons of the MOMP gene sequences of $C$. pneumoniae IOL-207 with those of other Chlamydia species gave homologies ranging from 67.2 to $72.4 \%$ for the nucleotides and from 63.5 to $75.9 \%$ for the amino acid sequences. This is reflected in the computer taxonomy, which shows all three species arising from a common ancestor, i.e. divergent evolution. Moulder (1988) suggests that the protochlamydiae, chlamydia-like organisms parasitic in invertebrates, are present-day descendants of a possible common ancestor.

The computer analysis classifies the present known MOMP sequences into three main branches. One branch consists of the four $C$. psittaci sequences, with a strong similarity between the sequence of $C$. psittaci A22/M ovine abortion agent and $C$. psittaci MnCal-10. The second branch consists of the single $C$. pneumoniae IOL207 sequence. The distinction made for this branch supports separate species status for this organism whilst its origin amongst $C$. psittaci suggests that $C$. pneumoniae diverged from $C$. psittaci. This concept is supported by the fact that neither $C$. psittaci nor $C$. pneumoniae produce inclusions with an iodine-staining reserve carbohydrate (Grayston et al., 1989b). C. trachomatis is classified by the computer analysis into two broad groups which correspond with the serogroups related to either serovar B or serovar C. Each of these serogroups is formed by the presence of a distinct subspecies epitope on MOMP (Conlan et al., 1988; Hayes et al., 1990). This subspecies epitope forms only a tiny portion of the MOMP variable sequences; it is remarkable that the computer analysis was able to consistently discriminate between them. Serovar $F$ is shown as being distinct from either of these complexes. Similarly, in the serological classification of C. trachomatis by micro-IF, serovar F does not belong clearly to either group (Wang \& Grayston, 1970).
One of the taxonomic criteria used to give species status to $C$. pneumoniae was the presence of unusual, pear-shaped EBs (Chi et al., 1987). It has been suggested that the tip of these EBs might be a specialized attachment structure (Kuo et al., 1988). We have seen similar structures in immature $C$. trachomatis EB and therefore re-examined $C$. pneumoniae ultrastructure ourselves. The electron micrographs clearly showed that the majority of EBs of both IOL-207 and ATCC VR 1310 were round. However, inclusions of $C$. pneumoniae contained a much lower proportion of fully developed EBs than those of $C$. trachomatis or $C$. psittaci. This may explain the greater difficulty in passaging C. pneumoniae in cell culture, as only mature EBs are infectious. We accept that there may be unknown technical reasons to explain our failure to observe significant numbers of pear-shaped EBs in this organism. Perhaps IOL-207 and VR 1310 differ in morphology from TW 183. In that case further work is required to ascertain the general validity of the ultrastructural criteria chosen for this new species.

Our work on the MOMP gene of IOL-207 and its taxonomic status fully supports species designation for C. pneumoniae. This is corroborated by the distinct clinical syndromes with which this organism is associated. One of the most controversial of clinical reports is the apparent association between antibody to $C$. pneumoniae and myocardial infarction (Saikku et al., 1988). One of the key problems in defining the clinical syndromes associated with this fastidious organism is the lack of specific diagnostic probes. We hope that the $C$. pneumoniae MOMP gene sequence presented here will facilitate the development of improved, non-culturedependent, diagnostic reagents for this newly recognized human pathogen.

The authors thank $\operatorname{Dr} M$. A. Pickett for synthesis of the oligonucleotides, Mr M. W. Watson for his advice, and Mr Watson and Miss S. J. Cooke for help in preparing the manuscript. M. W. Carter is in receipt of a Medical Research Council research studentship. This investigation received financial support from the Special Programme of Research, Development and Research Training in Human Reproduction, World Health Organization.

\section{References}

Baehr, W., Zhang, Y. X., Joseph, T., Su, H., Nano, F. E., Everett, K. D. E. \& Caldwell, H. D. (1988). Mapping antigenic domains expressed by Chlamydia trachomatis major outer membrane protein genes. Proceedings of the National Academy of Sciences of the United States of America 85, 4000-4004.

Bavoll, P., Ohlin, A. \& Schachter, J. (1984). Role of disulphide bonding in outer membrane structure and permeability in Chlamydia trachomatis. Infection and Immunity 44, 479-485.

Campbell, L. A., Kuo, C. C. \& Grayston, J. T. (1987). Characterization of the new Chlamydia agent, TWAR, as a unique organism by restriction endonuclease analysis and DNA-DNA hybridization. Journal of Clinical Microbiology 25, 1911-1916.

Chi, E. Y., Kuo, C. C. \& Grayston, J. T. (1987). Unique ultrastructure in the elementary body of Chlamydia sp. strain TWAR. Journal of Bacteriology 169, 3757-3763. 
Conlan, J. W., Clarke, I. N. \& Ward, M. E. (1988). Epitope mapping with solid-phase peptides: identification of type-, subspecies-, species- and genus-reactive antibody binding domains on the major outer membrane protein of Chlamydia trachomatis. Molecular Microbiology 2, 673-679.

Conlan, J. W., Ferris, S., Clarke, I. N. \& Ward, M. E. (1989). Surface-exposed epitopes on the major outer membrane protein of Chlamydia trachomatis defined with peptide antisera. Journal of General Microbiology 135, 3219-3228.

Conlan, J. W., Persson, K., Newhall, W. J. \& Ward, M. E. (1990). Mapping of discontinuous epitopes on the major outer membrane protein of C. trachomatis using synthetic peptides and monoclonal antibodies. In Chlamydial Infections, pp. 81-84. Edited by W. R. Bowie, H. D. Caldwell, R. P. Jones, P. Mardh, G. L. Ridgway, J. Schachter, W. E. Stamm \& M. E. Ward. Cambridge: Cambridge University Press.

Cox, R. L., Kuo, C. C., Grayston, J. T. \& Campbell, L. A. (1988). Deoxyribonucleic acid relatedness of Chlamydia sp. strain TWAR to Chlamydia trachomatis and Chlamydia psittaci. International Journal of Systematic Bacteriology 38, 265-268.

DWyer, R. St. C., Treharne, J. D., Jones, B. R. \& Herring, J. (1972). Chlamydial infection. Results of micro-immunofluorescence tests for the detection of type-specific antibody in certain chlamydial infections. British Journal of Venereal Disease 48, 452-459.

Felsenstein, J. (1980). PHYLIP 3.2 Manual. California: University of California Herbarium.

Forsey, T., Darougar, S. \& Treharne, J. D. (1986). Prevalence in human beings of antibodies to Chlamydia IOL 207, an atypical strain of Chlamydia. Journal of Infection 12, 145-152.

Grayston, J. T., Kuo, C. C., Wang, S. P. \& Altman J. (1986). A new Chlamydia psittaci strain, TWAR, isolated in acute respiratory tract infections. New England Journal of Medicine 315, 161-168.

Grayston, J. T., Kuo, C. C., Campbell, L. A. \& WANG, S. P. (1989a). Chlamydia pneumoniae sp. nov. for Chlamydia sp. strain TWAR. International Journal of Systematic Bacteriology 39, 88-90.

Grayston, J. T., Wang, S. P., Kuo, C. C. \& Campbell, L. A. (1989b). Current knowledge on Chlamydia pneumoniae, strain TWAR, an important cause of pneumonia and other acute respiratory diseases. European Journal of Clinical Microbiology and Infectious Diseases 8, 191-202.

Hamilton, P. T. \& Malinowski, D. P. (1989). Nucleotide sequence of the major outer membrane protein from Chlamydia trachomatis serovar H. Nucleic Acids Research 17, 8366.

Hatch, T. P., Allan, I. \& Pearce, J. H. (1984). Structural and polypeptide differences between envelopes of infective and reproductive life cycle forms of Chlamydia spp. Journal of Bacteriology 157, 13-20.

hayes, L. J., Pickett, M. A., Conlan, J. W., Everson, J. S., Ward, M. E. \& ClaRKE, I. N. (1990). The major outer membrane proteins of Chlamydia trachomatis serovars A and B : intra-serovar amino acid changes do not alter specificities of serovar- and $C$ subspeciesreactive antibody binding domains. Journal of General Microbiology 136, 1559-1566

Herring, A. J., Tan, T. W., BaXter, S., Inglis, N. F. \& Dunbar, S. (1989). Sequence analysis of the major outer membrane protein gene of an ovine abortion strain of Chlamydia psittaci. FEMS Microbiology Letters 65, 153-158.

Higgins, D. G. \& Sharp, P. M. (1988). Clustal; a package for performing multiple sequence alignments on a microcomputer. Gene 73, 237-244.

KIMURA, M. (1980). A simple method for estimating evolutionary rates of base substitutions through comparative studies of nucleotide sequences. Journal of Molecular Evolution 16, 111-120

Kuo, C. C., Chen, H. H., Wang, S. P. \& Grayston, J. T. (1986). Identification of a new group of Chlamydia psittaci strains called TWAR. Journal of Clinical Microbiology 6, 1034-1037.

Kuo, C. C., ChI, E. Y. \& Grayston, J. T. (1988). Ultrastructural study of entry of Chlamydia strain TWAR into HeLa cells. Infection and Immunity 56, 1668-1672.
Marrie, T. J., Grayston, J. T., Wang, S. P. \& Kuo, C. C. (1987) Pneumonia associated with the TWAR strain of Chlamydia. Annals of Internal Medicine 106, 507-511.

MOULDER, J. W. (1988). Characteristics of Chlamydiae. In Microbiology of Chlamydia, pp. 3-19. Edited by A. L. Barron. Florida: CRC Press.

Pickett, M. A., Ward, M. E. \& Clarke, I. N. (1987). Complete nucleotide sequence of the major outer membrane protein gene from Chlamydia trachomatis serovar L1. FEMS Microbiology Letters 42, 185-190.

Pickett, M. A., Everson, J. S. \& Clarke, I. N. (1988). Chlamydia psittaci ewe abortion agent: complete nucleotide sequence of the major outer membrane protein gene. FEMS Microbiology Letters 55, 229-234.

Saikku, P., Mattila, K., Nieminen, M. S., Huttunen, J. K., Leinonen, M., Ekman, M. R., Mäkelä, P. H. \& Valtonen, V. (1988). Serological evidence of an association of a novel Chlamydia, TWAR, with chronic coronary heart disease and acute myocardial infarction. Lancet 2, 983-986.

SambrooK, J., Fritsch, E. F. \& Maniatis, T. (1989). Molecular Cloning: a Laboratory Manual, 2nd edn. Cold Spring Harbor, NY: Cold Spring Harbor Laboratory.

Stephens, R. S., TaM, M. R., Kuo, C. C. \& Nowinski, R. C. (1982). Monoclonal antibodies to Chlamydia trachomatis: antibody specificities and antigen characterization. Journal of Immunology 128, 10831089.

Stephens, R. S., Mullenbach, G., Sanchez-Pescador, R. \& AGABIAN, N. (1986). Sequence analysis of the major outer membrane protein gene from Chlamydia trachomatis serovar L2. Journal of Bacteriology 168, 1277-1282.

Stephens, R. S., Sanchez-Pescador, R., Wagar, E. A., Inouye, C. \& URDEA, M. S. (1987). Diversity of Chlamydia trachomatis major outer membrane protein genes. Journal of Bacteriology 169, 3879-3885.

StePhens, R. S., WaGAR, E. A. \& SchoolNiK, G. K. (1988). High resolution mapping of serovar-specific and common antigenic determinants of the major outer membrane protein of Chiamydia trachomatis. Journal of Experimental Medicine 167, 817-831.

Su, H., Watkins, N. G., ZHang, Y. X. \& Caldwell, H. D. (1990). Chlamydia trachomatis-host cell interactions: role of the chlamydial major outer membrane protein as an adhesin. Infection and Immunity 58, 1017-1025.

TAYLOR-ROBINSON, D. \& WARD, M. E. (1989). Immunity to chlamydial infections and the outlook for vaccination. In Vaccines for Sexually Transmitted Diseases, pp. 67-85. Edited by A. Meheus \& R. E. Spier. London: Butterworths.

WANG, S. P. \& GraYston, J. T. (1970). Immunologic relationship between genital TRIC, lymphogranuloma venereum, and related organisms in a new microtiter indirect immunofluorescence test. American Journal of Ophthalmology 70, 367-374.

WARD, M. E. \& MURRAY, A. (1984). Control mechanisms governing the infectivity of Chlamydia trachomatis for HeLa cells: mechanisms of endocytosis. Journal of General Microbiology 130, 1765-1780.

Yuan, Y., Zhang, Y. X., Watkins, N. G. \& Caldwell, H. D. (1989). Nucleotide and deduced amino acid sequences for the four variable domains of the major outer membrane proteins of the 15 Chlamydia trachomatis serovars. Infection and Immunity 57, 1040-1049.

Zhang, H., Scholl, R., Browse, J. \& Somerville, C. (1988). Double stranded DNA sequencing as a choice for DNA sequencing. Nucleic Acids Research 16, 1220.

ZhaNG, Y. X., Stewart, S., Joseph, T., TAYLOR, H. R. \& CALDWELl, H. D. (1987). Protective monoclonal antibodies recognize epitopes located on the major outer membrane protein of Chlamydia trachomatis. Journal of Immunology 138, 575-581.

Zhang, Y. X., Morrison, S. G., Caldwell, H. D. \& Baehr, W. (1989). Cloning and sequence analysis of the major outer membrane protein genes of two Chlamydia psittaci strains. Infection and Immunity 57, 1621-1625.

Zhang, Y. X., Morrison, S. G. \& Caldwell, H. D. (1990). The nucleotide sequence of major outer membrane protein gene of Chlamydia trachomatis serovar F. Nucleic Acids Research 18, 1061. 